\title{
Change of Management Values in Estonian Business Life in 2007-2009
}

\author{
Anu Virovere \\ Tallinn University of Technology, Tallinn, Estonia \\ Estonian Entrepreneurship University of Applied Sciences, Tallinn, Estonia \\ Mari Meel \\ Tallinn University of Technology, Tallinn, Estonia \\ Eneken Titov \\ Tallinn University of Technology, Tallinn, Estonia \\ Estonian Entrepreneurship University of Applied Sciences, Tallinn, Estonia
}

\begin{abstract}
The paper deals with the change of management values in Estonian business life in the year of the rapid growth (2007) as compared with the year of hard decline (2009). The hypothesis is set that company managers do not have permanent values but they change accordingly to the change in economic conditions: in economical welfare situations business-managers more eagerly take larger responsibilities on ethical and philantrophical stages but in crisis only the lower stages (economical and legal ones) could be detained. In the paper, we firstly observe if values change in general and secondly we study if our pre-stated hypothesis holds. As the research method we use the method of critical incidents.
\end{abstract}

Keywords: core values, organizational values, economical crisis, sustainability, change of values

\section{Introduction}

In 2001, Drucker wrote:

The half century after the Second World War, the business corporation has brilliantly proved itself as an economic organization. In the next society, the biggest challenge may be in its social legitimacy—its values, its mission, its vision. The wave of distrust of business generated by the recent financial crisis has proved how right it was. (as cited in Paschek, 2009)

\section{Importance of CSR}

During the last decades, corporate social responsibility has become a more important topic in countries with developed economies. Discussions about it intensified already in the end of the 1960s with the rise of Milton

\footnotetext{
Anu Virovere, Ph.D. candidate, Lecturer, Chair of Marketing, Tallinn University of Technology; Management Institute, Estonian Entrepreneurship University of Applied Sciences.

Mari Meel, Ph.D., Associate Professor, Chair of Operations Management, Tallinn University of Technology.

Eneken Titov, Ph.D. candidate, Department of Business Administration, Tallinn University of Technology, Lecturer and Director of studies in Management Institute, Estonian Entrepreneurship University of Applied Sciences.

Correspondence concerning this article should be addressed to Eneken Titov, Estonian Entrepreneurship University of Applied Sciences, Suur-Sõjamäe 10a, Tallinn, 11415, Estonia. E-mail: eneken@eek.ee.
} 
Friedman's $(1963,1970)$ ideology: “There is one and only one social responsibility of business - to use its resources and engage in activities designed to increase its profits so long as it stays within the rules of the game". In accordance to globalization and strengthening of citizenship movement the self-consciousness of societies has risen and that has brought along the broadening of meaning of corporate social responsibility and also, sustainability has gained the leading position. The issue of sustainability has also become important due to the constant deterioration in environmental conditions and to the growth of exploitation of poor countries' resources.

On the other hand, at international climate conferences, the views of wealthy and underdeveloped countries often collide in the question of social responsibility towards nature: representatives of underdeveloped countries declare that wealthy countries have higher responsibility and must bear higher costs in protection of environment, while poor countries just cannot do it - they are not able to do more than stick to the basic survival game. The authors of this article were fascinated with the thought, how suggestible and changing are people's attitudes and way of thinking towards the change of economic conditions, for example, does the economic crisis, growing debt-load and poverty weaken the European Union's usually heightened responsibility towards nature and traditional efforts to lessen social inequity?

\section{Importance of Values}

Values are the ideas and beliefs that influence and direct our choices and actions (Gini, 2004). Values perform three functions for individuals and organizations — to defend against perceived threats (defensive values), to adjust to society (stabilizing values), and to foster movement toward self-actualization (growth values). All these three types of values are necessary and leadership definitely carries an important role in supporting these values and creating opportunities to do that (Hultman \& Gellerman, 2002). Effective leadership is about finding balance between economic success and well-being of your employees, and at the same time, it is about balance between society and the owners' demands. Therefore there are values by nature dynamic and influenced by economic environment. Other authors have also drawn attention to the change of values, for example, professor Lauristin (2008) has indicated the negative change of values in Estonian liberal society where borderless market economy has turned into total sales ideology, democracy has turned into egoistic competition between political parties and state-of-law has opened its doors to large-scale bureaucracy. Prevalently, Estonian manager's leadership style does not based on long-term management values. However, the enduring leadership is important in order to assure the sustainability. Enduring leadership is leadership that outlasts and transcends the individual—has been shown by research to be a predictor of long-term success (Moon, 2001).

Influence of crises to management. Today's managers are under strong pressure, especially during the economic crisis, because the rapid development of technology is forcing continuous change and new knowledge economy requires people who are devoted to their work. This can be considered a conflict situation where successful conflict management, turning the conflict into something productive, could help implement changes faster. Empirical research in Estonian organizations indicates that the best predictors of attitude towards change are ethical values and business ideological values (Alas, 2009). The ability to use crisis as a productive conflict and to base on true business ideological values in practice, would enable the organization to do the right changes as well as to be sustainable. To understand productive conflict we should consider conflict management strategies because they strongly influence subsequent interactions and outcomes, and conflict issues because they impact on 
conflicts management strategies through thoughts and feelings (De Dreu, 1997).

Conflict studies, carried out in Estonia show that Estonian leaders are lacking the knowledge of ethics and the will to resolve conflicts and understand the usefulness of a good and motivating work atmosphere. They do not realize that resolving conflicts and assisting the employees will be beneficial to the company and thereby make a major contribution to a more positive environment at work which significantly improves the employees' motivation and loyalty and the companies market position (Virovere, Kooskora, \& Valler, 2002).

Influence of working environment to job satisfaction. During the time of fast changes every organization needs creativity and innovation and the will of employees to go along with the changes. That means creating an environment where creativity is made possible. Organizational culture and microclimate are directly influenced by a manager's leadership style and leadership values. Studies carried out in Estonia show that especially people with an university education were most less satisfied with management and work satisfaction was the lowest among employees who had worked for the company for four and five years (Alas, 2009). Based on these results, it is possible to conclude that there is a lack of appreciation of the working environment and workers in Estonian organization.

\section{The Change of Management Values}

In this article, we tried to follow, how has the economic crisis influence the attitudes and management values of Estonian managers: Estonia's relatively fast and successful emerge into West-European (capitalist) society has often been explained by Estonian liberal-friedmanistic economic policy. After joining EU (in 2004) both the state and society here have started to force the businesses towards broader social responsibility and triple-bottom-line way of thinking is emerging. That means that a business (its management) should feel a broader responsibility towards social and ecological environment than just a legal one. It is logical to assume that during fast economic growth and relative wealth, the managers of companies were susceptible towards that new approach. But how are things now when companies have to concentrate on survival?

\section{Theory and Hypothesis}

\section{The Hypothesis}

Traditionally, corporate social responsibility is divided into four stages (look for, e.g., Carroll \& Buchholtz, 2009; Ferrell, 2008; Crane, 2010; etc.). Initially the model was proposed by Carroll soon in 1979 and advanced later (1999, 2009). The stages are differentiated as the ground ones-economical and legal, and the upper ones - ethical and philantrophical responsibilities. Logically, it could be supposed that in the situation of economical welfare business-managers are more eager to take more larger responsibilities on ethical and philantrophical stages and vice versa, in hard conditions of economical crisis it would be well enough if only the lower stages could be detained: at times of economic decline companies do not have means for philantropic causes and also in the case of ethical considerations it is observed that they would not cause additional expenses to the company.

\section{The Base of the Hypothesis}

That hypothesis seems to be supported by several earlier researches about the behavior of international organizations while locating territories of production. Reich (1992) shows that already since 1970s a trend is emerging where multinational enterprises, which are operating in the conditions of severe global competition and 
therefore are forced to innovate their production continuously keeping at the same time prices low, have nothing to do but to organize their work in the way as by placing their innovative units (research and development) in developed country, with highly educated and expensive work force, and their mass production in underdeveloped countries where the cost of work is low (as usual the lower cost of work force is accompanied with poorer labor conditions, absence of trade unions, lower safety protection etc.). This means that while locating their organization they follow (in territorial sense) Carroll's 4-level model, that higher-level responsibilities are considered only in the economically developed mother country. In poor countries, where production units are located, it is well if legal obligations are met at minimal range (according to the looser legislation base of under-developed countries) and the goal is making maximum profit. Several researches show that this is a continuous trend both in the US and EU. Also, it is mentioned that in the case of international competition it is inevitable (for example, Meel \& Saat, 2000). Crane (2010) shows that a growing number of multinationals as for example major European brands (Adidas, Reebok, Marks and Spencer etc.) as well as high-profile US brands (Disney, Levi's, Nike, Wal-Mart etc.) are involved in these location-based ethical conflicts.

The influence of crisis to an organization. Talwar (2009) wrote also that, in an era of global transformation, a narrow focus on strategies for enhancing profitability will no longer be sustainable, and organizations will need to seriously address long-term geopolitical social issues to attain sustainability with the adoption of universally acceptable ethical work standards. Practicing values is an important aspect for building a successful strategy and corporate culture. Based on the banking crisis it is also possible to draw parallels between organizational values and success. For example John Holland (2010) writes in his article that:

Top management weaknesses in the failing banks were important in undermining bank SCA and increasing relative vulnerability to crisis. Top management weakened other key resources such as risk management skills at middle management and operational levels by downplaying relevant knowledge. They appeared not to have had an explicit strategy to develop human capital, structural capital and relational capital at all levels in the bank or how to use it to improve risk control and intermediation. They downplayed ideas of adequate equity, and of sufficient cash. They sought to gain the maximum benefits of leverage ignoring the impact on bank functions and risk exposure.

Values and Maslow's Hierarchy. It can be logically assumed that the same tendency that works locally (territorially) should work in the time dimension, according to the change of economic conditions. During economic recession while most of any country's population fall to lower levels of Maslow's hierarchy of needs (main problems are making a living, lack of jobs is increasing) fundamentalistic claims rise also in managerial values: compared to developed societies only legal obligations are met, philantropic and ethical obligations will be left waiting for better times. In order to manage economical crises, there is a need to actualize Maslow's hierarchy upper needs - self-actualization and commitment, which would help to manage changes in the organization as well as to become innovative and sustainable. Based on the same logic, it can be assumed that company managers do not have constant moral certainties or values, but they shift according to the changes of economic conditions: During the good times, they tend to behave according to virtues—show up more caring, respect, valuing the employees etc.. During the recession, employees are fired more easily, in communication with the employees the managers are stricter, aggressive and autocratic. Only these values are considered that are connected to the company's economic success and sustainability.

Stability of values. On the other hand, researches that prove exactly the opposite (Collins, 2001) show that 
not all managers let their moral values to be shaken by the outside environment. Especially in times of recession like in 1929, just those companies that did not cross the line beyond their main values survived. Different researches (Collins, 2003; Drucker, 1972) even prove that sticking to core values is the key issue in an organization's sustainability. In really remarkable companies change is a constant factor, but they distinguish issues that should never be changed and those that should be opened to change. They distinguish their timeless core values and constant mission (that should never change) from ways of action and business strategies that have to be changed according to the changes in the world (Collins, 2003). Due to Fukuyama (2001), the sustainability of an organization is directly linked to the question of core values, although we have shared values, they may not yet produce social capital if the values are wrong. Profit orientation as a value has been replaced with a new value of sustainability (Drucker, 2003). Also, a research by Wilson and Eilertsen about strategic planning and survival during economic recession produced results that show the importance of core values. Although in 2009, organizations have more focus on cash flow and liquidity than they did a year ago, managers are experiencing greater internal pressures or conflicts inside the organization because of the changes in business environment, leadership is using the situation to make difficult decisions, and there is more leadership steering than managers had experienced in the past, despite these pressures, two-thirds of managers are convinced that their actions during the crisis remain aligned with the values and vision of the organization (Wilson \& Eilertsen, 2010).

The association between values and organization's success has also been researched as an important aspect. With reference to corporate ethical values, Hyman (1990) contendes that positive employee perception of top management's values and beliefs will lead to higher performance outcomes. Bergeron (2007) concludes that individuals that perceive high congruity between an organization's ethical values and their own will feel more motivated. Schwepker (2003) suggests that congruity between the ethical values of an employee and their organization will positively influence employee's performance.

Flowingly we are trying to research how constant the organizations' management values have been in Estonia during the last abrupt changes in the economical environment: At first, we observe if values change in general; as for second, we study if our pre-stated logical assumption holds-that while the economic situation deteriorates drastically, the basis of management values change and socially responsible and ethical behavior receives less consideration.

\section{Organizational Effectiveness vs. Values}

One important aspect that draws attention to the importance of values in an organization is the connection between organizational values and organization's success. Several modern researchers have pointed out that the constancy and direction of organizational values are some of the most important aspects to predict a company's success. For example, Kotter and Heskett have written in their book Corporate Culture and Performance, that companies with strong adaptive cultures based on shared values outperformed other companies by a significant margin. For example, they show how valuing interest groups influence success-companies that emphasized all stakeholders - employees, customers and stockholders, and focused on leadership development, grew four times faster than companies that did not. They also found that these companies had job creation rates seven times higher, had stock prices that grew 12 time faster and profit performance that was 750 times higher than companies that did not have shared values. Collins and Porras (2003) confirm the same tendency in their book Built to Last, where 
they compared organizations with gyroscopes which keep the organizations in balance-the main values stay changeless, but other organizational processes continue to change. They show that companies that consistently and in long-term focused on building strong corporate cultures outperformed companies that did not by a factor of six and outperformed the general stock market by a factor of fifteen. Beu, Buckley and Harvey (2003) set the organizational values even on a higher position while they say that business, as a type of society, is possible only within a certain social context of institutions, agreements, understandings and shared values.

\section{Shared Values and Job Performance}

In the case of value-based leadership, it has been discussed that in reality, all organizations are value-driven. But what is important is the fact whether the values are conscious, shared and lived, or unconscious and undiscussed. When values are unconscious and undiscussed, the culture of the organization usually reflects the personality of the leader. Unless the organization has a very evolved leader, it is unlikely that there will be an alignment between employees' personal values and the leader's values (Fitzgerald \& Desjardins, 2004). At the same time, a high consensus in followers' perception of their leader does not assure that performance is in line with company expectations. Consequently, it is proposed that high work values moderate the relationship between consensus and performance (Schyns, 2006).

When values are conscious and discussed, it is likely that they are shared and lived. In this case, there is a stronger possibility that that there is an alignment between employees' personal values and the organization's values (Fitzgerald et al., 2004). Westerman and Cyr (2004) analyzed personality and work environment congruence and found that value congruence was the best predictor of job satisfaction. Verquer, Beehr and Wagner (2003) also found that value congruence and turnover intent are in strong positive correlation with each other. One other important result was that when individuals' values match those of their organization, they are less likely to leave.

A whole theory has been created to explain the connections between organizational environment and the individual (the person-environment fit theory), that assumes that individuals prefer an environment that possesses characteristics (e.g., values, beliefs) that are similar to their own (Kroeger, 1995). The theory says that if people fit well with an organization, they are likely to exhibit more positive attitudes and behaviors.

\section{Leadership and Shared Values}

Therefore it is important to understand while connecting values and organizational success to each other whether the behavior of the organization is based only on the manager's or the organizations shared values. It is also important that the organizational values cannot be seen separately of leadership and management behavior. Terrence Deal and Allan Kennedy found out that leaders should not hesitate to communicate their values widely and advocate for them vigorously. They considered important that leaders create a guiding vision and shape shared values. James MacGregor Burns believes that leaders should help followers reframe their understanding of core values from self-interest to a broader view of the common good (Whitmire, 2005). Peter Drucker (2003) wrote:

The leader is visible; he stands for the organization. He may be totally anonymous the moment he leaves that office and steps into his car to drive home. But inside the organization, he or she is very visible, and this isn't just true of the small and local one, it is just as true of the big, national, or worldwide one. No matter that the rest of the organization doesn't do it; the leader not only represents what we are, but, above all, what we know we should be. 
Also, Alas and Tuulik (2004) emphasized the importance of managers in strengthening the values and believed that common values can be attained through improved training and improved management practices and also by having the right leaders for the job.

We have no reason doubting the importance of behavior of managers in influencing the values of an organization but more important become the question—how important are their actions in forming organization's values in the eyes of the managers themselves. For example, based on the research of McKinsey and Co in 2009 (763 executives who responded) two most important activities for managers were "leadership (shape and inspire the actions of others) $49 \%$ of respondents and "direction" (capacity to articulate where the company is heading and how to get there) $46 \%$ of respondents, but activity "foster a shared understanding of values" was important for only $8 \%$ of respondents. Researchers claim that ensuring shared values has become less important since the economic crisis began, while the other two qualities have become more significant (Wartzman, 2009).

Therefore, of critical importance is how much do manager's value spreading and following the organizational values inside the organization. While getting over the crisis those organizations survive that have kept to the same core values in the long run.

Consultant Kane (2009) has described how core values affect performance and managers definitely have an important role in that process. She believes that: "Managers and others throughout the organization give priority attention to what is stressed in the corporate values system and this in turn supports producing the priority results". If the employees have acknowledged the core values they make better decisions, because they are guided by their perception of the shared values. Also, if employees share the values then they are more likely to recognize that they are an important part of the organization. They are more motivated because life in the company has more meaning for them. They work harder because they are dedicated to what is expressed in the organization's core values.

\section{Values Which Predict Success}

Peters' and Waterman's seven values of excellence. Several authors have investigated which organizational shared values predict success. Many researchers have been carried out where connections between different shared values and organizational success have been investigated. Boxx, Odom and Dunn (1991) used Peters' and Waterman's seven values of excellence, stated in 1982 (superior quality and service, innovation, importance of people as individuals, importance of details of execution, communication, profit orientation, and goal accomplishment) and analyzed their correlation to work satisfaction. Although positive correlation was found among highway and transportation managers, the results can be generalized because later researches also confirm correlations between values and work satisfaction.

Hultman's 15 values. Hultman has brought out 15 values (self-directed learning, adapting to change, balance, seeking opportunities in the midst of uncertainty, utilizing ability, distributing rewards fairly, finding satisfaction in work, serving mutual interests, working as an owner, prizing wisdom, being authentic, seeking truth, celebrating differences, accepting people and viewing people as ends in themselves), that in his opinion are particularly relevant for success in this current business climate of global competition and instant communication. Those values also happen to be humanistic values that foster wholeness and integration (Hultman \& Gellerman, 2002). Hultman also stresses the importance of connection between organizational and individual values: "Effective culture is one that successfully balances individual and organizational values, that is, walking the 
tightrope to success" (Hultman \& Gellerman, 2002). Based on research he also claims that profits are higher when individual and organizational values are aligned. He writes that many organizational problems can be traced back to people's values (Hultman \& Gellerman, 2002).

Risk-taking value and success. Organizational success has been also tied to risk-taking. Zukerman and Kuhlman's (2000) study show that generalized risk taking is related to scales for impulsive sensation seeking and aggression. Logically, it could be guessed that risk-taking is rather positively connected to organization's success but based on several researches the connection seems to be indeed negative. Rauch and Frese (2002) show that high risk-taking is negatively associated with business success, Estola (2004) found that risk-taking is a contributory factor to the unethical in business. Based on theory another value that is negatively correlated to organization's success is concentrating of profit-Amos and Weathington found that there are general negative connotations associated with organizations that individuals perceive as only valuing profit (Amos \& Weathington, 2008).

\section{Ethical Values and Success}

Correlations between ethical values and different constructs (devotion, work satisfaction) have been studied relatively much also they have proven to have positive correlation with organization's success. For example, Hunt, Wood and Chonko (1989) discovered a positive association between corporate ethical values and organizational commitment, Singhapakdi, Kraft, Vitell and Rallapalli (1995) proved that those employees who exhibited a greater degree of belief in corporate ethical values placed more importance on ethical approaches and social responsibility, thus leading to the overall increased effectiveness of the organization. In the next study Singhapakdi, Rao and Vitell (1996) found that an organization that appears to have ethical values shared by its employees is relying on the ethical reasoning of its decision makers.

DeGeorge ties organization's success to ethical values more directly, assuming, based on the study, that the freedom of business to make profit is limited by the values of fairness, equal opportunity, honesty and truthfulness (DeGeorge, 1999) and therefore setting ethical values on the first place above all other values. Others have also mentioned the importance of ethical values. Barnow, King and Krumina (2003) tied ethical behavior to social capital, based on the fact that making human relations more ethical directly increases the value of social capital. Alas and Tuulik (2004) develop the idea of importance of ethical values further, stressing organization's ethical competencies by which they mean a company's ability to change its activities so they conform to a set of ethical standards, and so, to manage its own values and commitments. Therefore, when an organization bases its actions of ethical values they also appear in organizational behavior as ethical competencies and thereafter the behavior of the organization as a whole influences the employees to work harder and finally the performance of the organization rises.

In different researches especially one value has been demonstrated as an important ethical value, which is fairness (Moorman, Niehoff, \& Organ, 1993; Clemmer, 1993; Oliver \& Swan, 1989). On one hand fairness is important as an organization's core value, but employee's perception of how fairly he or she is treated can become even more important. Perceived fairness is a key antecedent to commitment, job performance and job satisfaction. The value of employee-centeredness can also be discussed through two aspects. The importance of people as individuals' value facet significantly related to job satisfaction. This circumstance indicates that 
employees who perceive their organization as valuing employees as individuals report higher job satisfaction (Amos \& Weathington, 2008).

\section{Research}

\section{Research Methodology}

This research can be called critical discourse analysis (more information about this in Laherand, 2008, pp. 329-330, or Fairclough, 2002, pp. 91-116). The same principles have been used in other researches in Estonia by Lauristin (2000)—investigating articles appearing in two newspapers during 10 years that were collected out of certain two month issues of each year (Lauristin's analysis is centered on typical metaphors that carry the means of translating social changes).

In a similar way, we use documents, namely business magazine Director's 2007 and 2009 issues as the database for our qualitative study. In 2007, Estonian economy was in the phase of fast growth, quite fast inflation accompanied that also. Wages (and prices) rose, there was lack of work force, not lack of work. It could be guessed that in that kind of environment the managers of companies were considerate towards their employees (valued them relatively highly) and acted also more broadly responsible towards other interest groups (taking higher stages of model of Corporate Social Responsibility).

In 2009, Estonia was already in deep economic crisis, lack of work was serious, companies had hard time selling their products both here and outside markets, several companies had gone into bankruptcy, both wages and prices had stagnated - we guessed that in that kind of situation the values of entrepreneurs (in Estonia: managers of companies but also co-owners) would comply with lower stages of model of Corporate Social Responsibility.

As it can be seen we used magazine articles in our study. The articles were interviews with managers of companies - that kind of database can be named as documents. Hirsjärvi (2005) suggests data gathering method based on documents, mostly along with other data gathering methods but it can be used as an independent method also (Flick, 2006, pp. 245-246).

To ensure validity and reliability of our investigation we used Creswell's (2003, pp. 196-197) proposed researcher triangulation which means using different observers to discover or minimize mistakes that come from the researcher's person, like it was said above, we were reading the articles from business magazine director, issues of 2007 and 2009. Each of them included about 10-30 business related articles that in our view represented important values of that particular time in our business world. Two researchers read independently each article and wrote down the values that the article carried. One hundred and fifty seven articles in 2007 issues were read and 401 values were written down. One hundred and sixty five articles in 2009 issues were read and 340 values were written down.

Next the discovered values were analyzed. Values inside the article that we agreed upon us added to the database. If different values appeared, our third researcher read the article, too. If her opinion was the same as either of the two others those values were added to the database, if not, then these values were not added. In 2007, there were 27 and in 2009, 30 articles that did not show any clear values. The values added in the database were analyzed and similar were gathered together. If necessary the same articles were re-read to make sure that similarly named values would actually represent values with the same meaning. The results of research are shown in the Appendix A. 


\section{Discussion}

This research showed an important change of values in the period of 2007-2009 (see Appendix) that can be described by Estonian economy reaching deep economic crisis, coming from very fast economic growth. That was also accompanied by very fast growth of unemployment (the number of unemployed people doubled in a year-2008 IV quarter, 53,500 people, and 2009 IV quarter, already 106,700 people. Estonian population is approximately $1.3 \mathrm{mil}$ ). In the beginning of 2010, unemployment continued to rise. This has been the highest level of unemployment in Estonia in 12 years (Toompark, 2010).

For many companies, it was more useful to go into bankruptcy than to continue working. In 2009 in Estonia 1,055 businesses and 14 non-profit organizations were estimated unable to pay their debt which meant that the number of bankruptcies rose compared to 2008, 2.5 times, in numbers 623 companies. Statistics show that every 133th business, that is $0.75 \%$ of all businesses in Estonia went into bankruptcy (Karner, 2010).

Innovation and creativity. If we analyze the change of values (see Appendix A), then we can bring out both important changes and also those values that were left at the same level and were mutually important both in 2007 and 2009. Innovation and creativity turned out to be very important. They are directly connected to fast changes in the society and the need to stay in competition and keep up with the fast development in technology.

Innovativeness, creating something new is also named as most important by professor Lauristin (Raun, 2010), who states that these are the keys of bringing a country and an organization of the crisis. In her words, it is clear that innovativeness is needed in Estonia, but it is another question if we can meet those needs. According to our research, creativity and innovation are important values by the number of times they appeared, but their change in time was not noted. If we talk about knowledge management as a management instrument in a modern organization, innovation being presented as a value must be considered as an important issue, because the innovation views and creativeness are the significant parts in process of knowledge management development.

Risk-taking. Economic crisis brings out the need to rising professionalism and risk-taking. If in economy taking risks is seen as a possibility to achieve higher results, then this study also confirms that in difficult economic conditions taking risks may mean ignoring ethical principles and laws. In order to use the risk to come out of the crisis one must in full awareness use the principles of risk management. Risk management can thus be defined as a systematic application of management practices to identifying, analyzing, treating, and monitoring uncertainties to better advice crisis management (Robert \& Lajtha, 2002).

The rise of professionalism and courage to risk as values and using knowledge management is connected to the opportunity to use the situation for one's own advantage, and therefore be more competitive in the market. The point of view is the courageous survive. The crisis gives an extraordinary possibility to change both organizations and economic structure. Managers who miss the opportunity to use the crisis for long-term changes not only waste a good possibility, but also make re-appearance of other crises possible (George, 2010).

Teamwork. The possibility for long-term changes is connected to crisis management and knowledge management. Knowledge management itself will not solve the problems. The active involvement of top management and the board and the exercise of their power on these knowledge matters are vital. As knowledge is vital the organizations need active teamwork by employees and management to implement changes. At the same time, research showed that in times of crisis, the importance of teamwork as a value has diminished greatly. Therefore, it is contradictory that knowledge management is important for coming out of the crisis but at the same 
time Estonian managers do not value one of the main competencies of using it-teamwork. The reasons of lack of teamwork can be uncertainty and fear of losing one's job. Therefore, everybody is concerned about keeping the status quo instead of actively searching for new opportunities. The same results are backed up by the fact that communication as a value diminished because teamwork means communication. It is difficult to conceive of how such learning, knowledge and regulation can control or change human nature, especially greed.

Motivation and valuing the employee. Analyzing these values that changed remarkably in negative direction, motivation and valuing the employee must be pointed out. The diminishing of these values can be explained by the fact that having a job became a value of its own during the time or crisis and being motivated while having a job was elementary. Simply put it means that for employees the content of the job, job environment, management activities and other factors that influence work motivation and satisfaction became less important because lack of work-force that described the earlier period had been replaced by massive lack of work. Changed economic conditions brought out sparingness and saving as values that represent in general the whole operations of an organization - the main savings were made in employee wages (in 2009 III quarter, Estonian average salary was 11,770 crowns. The drop in annual average salary was $5.9 \%$. Still in 2008, the rise in average salary was $14.8 \%$, average salary began to drop in the I quarter of 2008 (Toompark, 2010)), number of jobs, expenses on trainings and other employee-related costs. Because of that responsibility for the employees diminished as the employers often felt they had power over them (many possible new employees around). Although courage and risk as values appeared more often, it seems contradictory that aggressiveness and competition diminished. This tendency can be explained by several cartel agreements occurring during these times (Prangli, 2008).

Crisis management with full awareness. To use crisis as a possibility to develop and change economy, it is necessary to use crisis management with full awareness. Crisis management is broader in scope and can be defined as a set of ongoing and systematic processes for identifying, analyzing, and treating business crises by applying management practices (Mitroff, 1994). Crisis management frameworks can be categorized according to those that focus on why crises happen, which is termed operation-oriented frameworks, and those that focus on how crises impact organizations and the tasks that need to be performed in order to lessen their impact, which is termed process-oriented frameworks (Wang, 2009).

If we analyze the differences among negative values that appeared it shows that in the earlier period overbuying and overbidding, brutality and shrewdness were condemned. But in 2009, more organization-centered behaviors were brought out as negative values-too much profit-centeredness, lack of mission, not trusting employees and too little creativity.

\section{Results and Conclusion}

In this paper, we researched the constancy of management values in times of economic crisis. We started out with the hypothesis that in hard economic conditions less attention is paid to ethical values and economy-based values will take their places. At the same time, several earlier researches made us doubt that hypothesis. They said that those companies whose core values and mission stayed constant in long term survived any crisis better. In this research we followed the change in management values in 2007 (time of rapid economic growth) and 2009 (deep crisis in economy). 
Moorman points out that the most important value is fairness and it should even be one of the core values of the organizations, but at the same time our research shows that the fairness as a value is decreased at the time of crisis. Comparing the values discovered by our research to values brought out by Peters, Waterman and Hultman, we can admit that four values of Peters et al. were also discovered in our study-superior quality and service, innovation, importance of people as individuals, communication. But in our study communication and importance of people diminish during the crisis. Other values, important by Peters et al.-importance of details of execution and goal accomplishment did not show up as significant in our study. Comparing our results to Hultman's important values we can mention fairness and honesty, whereby the occurrence of honesty is increased and occurrence of fairness is significantly decreased-it confirms the decrease of importance of ethical values in the time of crisis.

The management values analysis 2007 versus 2009 shows a certain change in values but does not bring out the need for knowledge management and learning as a value. Also Holland (2010) claims that knowledge and lack of it was also deeply implicated in the crisis and in many of the above problems, and hence addressing these issues will be part of the solution.

What are the conclusions of that research? We must admit that there has been an important shift among management values in the period of 2007-2009. In the centre position, there is survival, not so much competition but still sustainability is tied to innovation and creativity.

Sustainability in a society, in Estonian economy coming out of the economic crises means that our economic structure also needs a change to be competitive. If Estonia has clearly approached the EU and developed countries economies characteristics in some ways, then we cannot say that about our economic structure's dynamics unfortunately (Terk, 2007). James Collins and Jerry Porras of Stanford University (2003) found that the main differences between the visionary companies (companies that survived the economic crisis) and the control group with which they were compared were in their approach to values. All the visionary companies had a powerful sense of their identity and what they wanted to achieve. Managers in global business can help their firms to be successful and to minimize ethical conflict in several ways. The most important in sustainability of an organization is that the core values stay the same.

Surviving is also connected to opposite values, saving and frugality on one side but also courage and risk on the other. Diminishing competition seems illogical but it can be explained by making cartel agreements that represents growth in unethical behavior. Cartel agreements are connected to the need to lessen the competition on the market and therefore ensure the survival of your own organization but at the same time this activity shows ignorance of ethical values. At the same time, other researches (Alas, 2009) show that having ethical values present in the organization is an important prerequisite for employees to go along with changes.

As the research confirms the importance of ethical values like respect, valuing of employees, justice and responsibility has diminished remarkably, the hypothesis that was set-in hard times economic concerns prevail over ethical and philantropical ones-is proved right. At the same time the will of an organization to keep the status quo and not to use the crisis as an opportunity for positive changes points out.

In conclusion, it can be said that the year 2007 is described by innovation and creativity, communication and caring as values, also valuing the employee, stability and intentionality. In 2009 innovation, creativity and caring remain important but ethical values as fairness, respect and valuing the employee lost their significance. 


\section{References}

Alas, R. (2009). The impact of work-related values on the readiness to change in Estonian organizations. Journal of Business Ethics, 86, 113-124.

Alas, R., \& Tuulik, K. (2004). Ethical values and commitment in Estonia companies. EBS Review, 19, 73-83.

Amos, E. A., \& Weathington, B. L. (2008). An analysis of the relation between employee-Organization value congruence and employee attitudes. The Journal of Psychology, 142(6), 615-631.

Barnowe, J. T., King, J., \& Krumina, M. (2003). Ethical aspects of value-based relationship. EBS Review, 17, 98-103.

Bergeron, D. M. (2007). The potential paradox of organizational citizenship behavior: Good citizens at what cost? The Academy of Management Review, 32(4), 1078-1095.

Beu, D. S., Buckley, M. R., \& Harvey, M. G. (2003). Ethical decision-making: A multidimensional construct. Business Ethics: A European Review, 12(1), 88-107.

Boxx, W. R., Odom, R. Y., \& Dunn, M. G. (1991). Organizational values and value congruency and their impact on satisfaction, commitment, and cohesion: An empirical examination within the public sector. Public Personnel Management, 20, $195-206$.

Carroll, A. B. (1979). A three dimensional model of corporate social performance. Academy of Management Review, 4, 497-505.

Carroll, A. B. (1999). The pyramid of corporate social responsibility: Toward the moral management of organizational stakeholders. Business Horizons, 7-8, 39-48.

Carroll, A. B., \& Buchholtz, A. K. (2009). Business and society: Ethics and stakeholder management (7th ed.). South-Western, Cincinnati.

Clemmer, E. C. (1993). An investigation into the relationship of fairness and customer satisfaction with services, Justice in the workplace: Approaching fairness in human resource management (pp. 193-207). Hillsdale, N.J.: L. Erlbaum Associates.

Collins, J. (2002). Heast suurepäraseks (Good to great). Tallinn: OÜ Väike Vanker,.

Collins, J., \& Porras, J. I. (2003). Loodud kestma (Built to last: Successful habits of visionary companies). Tallinn: OÜ Väike Vanker.

Crane, A., \& Matten, D. (2010). Business ethics: Managing corporate citizenship and sustainability in the age of globalization. Oxford University Press.

Creswell, J. (2003). Research design: Qualitative, quantitative and mixed method approaches. Thousand Oaks, Sage.

De Dreu, C. K. W. (1997). Productive conflict: The importance of conflict management and conflict issue. In C. K. W. De Dreu, \& E. Van de Vliert (Eds.), Using conflict in organizations (pp. 9-22). London: Sage.

DeGeorge, R. T. (1999). Business ethics. New Jersey: Upper Saddle River, Prentice-Hall.

Drucker, P. F. (1972). Concept of the corporation. New York: John Day Co..

Drucker, P. F. (2003). Juhtimise väljakutsed 21. sajandiks (Management challenges for the 21st century). Tallinn: Pegasus.

Estola, M. (2004). About the ethics of business competition. Electronic Journal of Business Ethics and Organization Studies, 9(2), $10-23$.

Fairclough, N. (2001). Language and power (2nd ed.). Harlow: Longman.

Ferrell, O. C., Fraedrich, J., \& Ferrell, L. (2008). Business ethics: Ethical decision making and cases (7th ed.). Boston: Houghton Mifflin.

Fitzgerald, G. A., \& Desjardins, N. M. (2004). Organizational values and their relation to organizational performance outcomes. Atlantic Journal of Communication, 12(3), 121-145.

Flick, U. (2006). An introduction to qualitative research. London: Sage.

Friedman, M. (1963). Capitalism and freedom. Chicago: University of Chicago Press.

Friedman, M. (1970). Social responsibility of business. New York Times Magazine, 9.

Fukuyama, F. (2001). Suur vapustus: inimloomus ja ühiskondliku korra taastamine (The great disruption). Tallinn: Tänapäev.

George, B. (2010). Kriisi 7 õppetundi. Juhtimise käsiraamat (The seven lessons of crisis). Tallinn: Tea Kirjastus.

Gini, A. (2004). Moral leadership and business ethics. In J. B. Ciulla (Ed.), Ethics, the heart of leadership (pp. 23-43). Praeger.

Hirsjärvi, S., Remes, P., \& Sajavaara, P. (2005). Uuri ja kirjuta. Tallinn: Medicina.

Holland, J. (2010). Banks, knowledge and crisis: a case of knowledge and learning failure. Journal of Financial Regulation and Compliance, 18(2).

Hultman, K., \& Gellerman, B. (2002). Balancing individual and organizational values: Walking the tightrope to success. San Francisco, C.A.: Jossey-Bass/Pfeiffer.

Hunt, S. D., Wood, V. R., \& Chonko, L. B. (1989). Corporate ethical values and organizational commitment in marketing. Journal 
of Marketing, 53, 79-90.

Hyman, M. R. (1990). Ethical codes are not enough. Business Horizons, 33(2), 15-23.

Kane, M. J. (2009, May 24). CEO’s speak on leadership-Authenticity. The CEO Refresher.

Karner, K. (2010, April 6). Pankrottide arv kümnendi kõrgeim (The number of bankruptcies is the highest). Äripäev online.

Kotter, J. P., \& Heskett, J. L. (1992). Corporate culture and performance. New York: The Free Press.

Kroeger, N. W. (1995). Person-environment fit in the final jobs of retirees. The Journal of Social Psychology, 135, 545-552.

Laherand, M. L. (2008). Kvalitatiivne uurimisviis (Qualitative research). Tallinn: OÜ Infotrükk.

Lauristin, M. (2000). Kas see ongi siis nüüd see Eesti aeg? Muutuste diskursus Eesti ajakirjanduses. In M. Lauristin (Ed.), Kõnelev ja kõneldav inimene: Eesti erinevate eluvaldkondade diskursus (pp. 63-84). Tallinn: TPU.

Lauristin, M. (2008, December 31). Kas hirm sünnitab müüte või muutumisjulgust? Eesti Päevaleht, Möte.

Meel, M., \& Saat, M. (2000). International enterprises and trade unions. Journal of Business Ethics, 27, 117-123.

Mitroff, I. I. (1994). Crisis management and environmentalism: A natural fit. California Management Review, 36(2), 101-113.

Moon, Ch., \& Bonny, C. (2001). Business ethics. Profile Books Ltd..

Moorman, R. H., Niehoff, B. P., \& Organ, D. W. (1993). Treating employees fairly and organizational citizenship behavior: Sorting the effects of jobs satisfaction, organizational commitment, and procedural justice. Employee Responsibilities and Rights Journal, 6(3), 209-225.

Oliver, R. L., \& Swan, J. E. (1989). Consumer perceptions of interpersonal equity and satisfaction in transactions: A field survey approach. Journal of Marketing, 53(2), 21-35.

Paschek, P. (2009). The responsibility of management consultants. Harvard Businesse Review, 11, 79-80.

Prangli, T. (2008, March 3). Kartellikokkulepped on Eestis avalik saladus (The cartel agreement-The open secret in Estonia). Äripäev online.

Rauch, A., \& Frese, M. (2002). Psychological approaches to entrepreneurial success: A general model and an overview of findings. In C. L. Coopers, \& I. T. Robertson (Eds.), International review of industrial/organizational psychology (pp. 101-142). Chichester: Wiley.

Raun, A. (2010, March 22). Lauristin: Eesti arengut takistab arendamata inimene (Non-developed human hinders Estonian progress). Postimees online.

Reich, R. (1992). The work of nations. New York: Vintage Press City.

Robert, B., \& Lajtha, C. (2002). A new approach to crisis management. Journal of Contingencies and Crisis Management, 10(4), 181-191.

Schwepker, C. H. (2003). An exploratory investigation of the relationship between ethical conflict and salesperson performance. Journal of Business and Industrial Marketing, 18(4-5), 435-446.

Schyns, B. (2006). are group consensus in leader-member exchange ( $\operatorname{lmx}$ ) and shared work values related to organizational outcomes? Small Group Research, 37(1), 20-35.

Singhapakdi, A., Kraft, K. L., Vitell S. J., \& Rallapalli, K. (1995). The perceived importance of ethics and social responsibility on organizational effectiveness: A survey of marketers. Journal of the Academy of Marketing Science, 23, 49-56.

Singhapakdi, A., Rao, C. P., \& Vitell, S. J. (1996). Ethical decision making: An investigation of services marketing professionals. Journal of Business Ethics, 15, 635-644.

Talwar, B. (2009). Comparative study of core values of excellence models vis-à-vis human values. Measuring Business Excellence, 13(4).

Terk, E. (2007). Eesti majandusstruktuuri tulevik (The future of estonian economic structure). In M. Heidmets (Ed.), Eesti Inimarengu aruanne (pp. 88-112). Tallinn: Eesti ekspressi kirjastus.

Toompark, T. (2010, February 25). Statistika: töötute arv aastaga kahekordistunud (Statistica). Äripäev online.

Toompark, T. (2010, January 4). Statistika: keskmine palk liigub languse suunas (Statistica). Äripäev online.

Verquer, M. L., Beehr, T. A., \& Wagner, S. H. (2003). A meta-analysis of relations between person-organization fit and work attitudes. Journal of Vocational Behavior, 63, 473-489.

Virovere, A., Kooskora, M., \& Valler, M. (2002). Conflict as a tool for measuring ethics at workplace. Journal of Business Ethics, 39(1-2).

Wang, W. T. (2009). Knowledge management adoption in times of crisis. Industrial Management and Data Systems, 109(4).

Wartzman, R. (2009, February 11). Executives are wrong to devalue values. BusinessWeek Online.

Westerman, J. W., \& Cyr, L. A. (2004). An integrative analysis of person-organization fit theories. International Journal of Selection and Assessment, 12, 252-261. 
Whitmire, K. (2005). Leading through shared values. Leader to Leader, 37, 48-54.

Wilson, J. W., \& Eilertsen, S. (2010). How did strategic planning help during the economic crisis? Strategy and Leadership, 38(2). Zurkerman, M., \& Kuhlman D. M. (2000). Personality and risk taking: Common biosocial factors. Journal of Personality, 68(6), 999-1029.

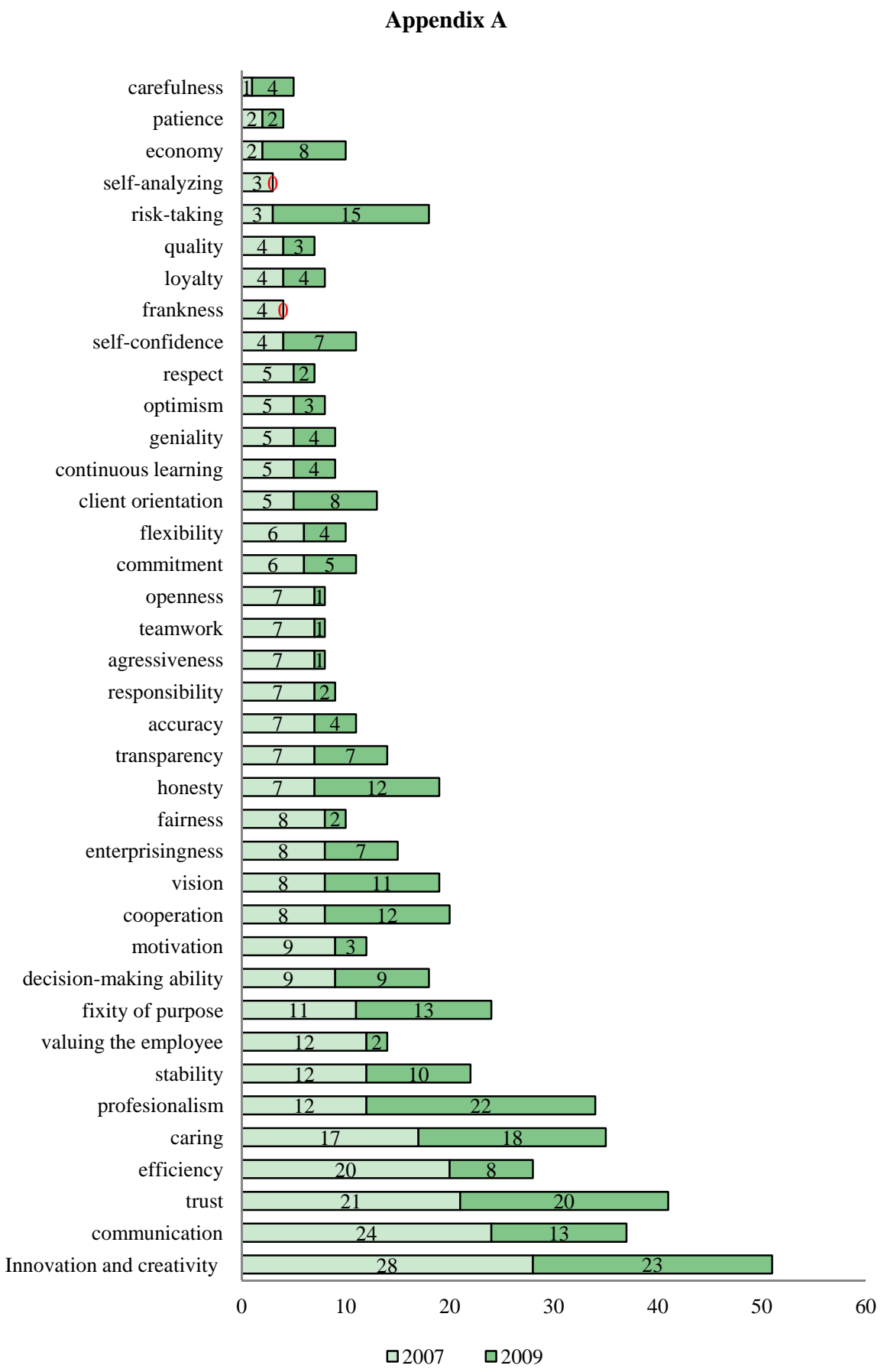

Figure A1. Change of management values in Estonia in business life between 2007-2009, by the frequencies of the occurrence of values. 